\title{
Financial flows and the New Developmentalism
}

\author{
Fluxos financeiros e o novo desenvolvimentismo
}

FERNANDO J. CARDIM DE CARVALHO $*$, *, 必

RESUMO: O Novo Desenvolvimentismo focou sua atenção sobre os problemas comerciais criados, em grande medida, pelas divergências entre a taxa de cambio que mantem a conta corrente do balanço de pagamentos em equilíbrio e o que chama de taxa de cambio de equilíbrio industrial, a taxa que preservaria a competitividade das firmas industriais que operem na fronteira do estado-das-artes. O ND reconhece que essas taxas podem ser perturbadas por fluxos financeiros, mas o papel de movimentos da conta de capitais pode estar sendo subestimado. Este trabalho argumenta que fluxos financeiros têm sido realmente subestimados, o que pode tornar mais difícil a elaboração de politicas eficazes para corrigir o problema da sobrevalorização cambial.

PALAVRAS-CHAVE: Novo desenvolvimento; taxas de câmbio; teoria da paridade da taxa de juros.

ABSTRACT: New Developmentalism has focused its attention on trade problems created, to a large measure, by the divergences between the exchange rate that keeps the current account of the balance of payments balanced and what it calls industrial equilibrium exchange rate, the rate that would preserve the competitiveness of manufacturing firms operating at the state-or-art frontier. ND acknowledges that these rates may be disturbed by financial flows, but the role of capital account movements may be underestimated. The paper argues that financial flows have indeed been underestimated, which may make more difficult to devise efficacious policies to correct the problem of currency overvaluation.

KEYWORDS: New Developmentalism; Exchange Rates; Interest Rate Parity Theory. JEL Classification: F31; O11; O14.

\section{INTRODUCTION}

The expression new developmentalism (hereafter ND) has been in circulation in Brazil for some years now. Generally, it refers to a set of policies directed at

\footnotetext{
* Professor Emérito de Economia da Universidade Federal do Rio de Janeiro. * Senior Research Scholar, The Levy Economics Institute of Bard College. E-mail: fjccarvalho@uol.com.br. Submitted: 8/May/2017; Approved: 26/June/2017.

My thanks to Luiz Carlos Bresser-Pereira for his comments on a previous version of this paper.
} 
pushing economic growth rates up. They also seek to pursue structural changes to stop deindustrialization, which is believed to have resulted from premature trade and financial liberalization coupled with policies that overappreciated, in a sustained way, the national currency.

Characterized in these terms, ND includes all the variants of economic thought that share a concern with the premature shrinkage of the manufacturing sector the country built during the import substitution period and beyond. The identity among ND-ers is established by their agreement around policies and goals. Theoretical differences tend to be deemphasized in favor of political efficacy. ${ }^{1}$

While policy agreement is usually enough for those dedicated to public debates to establish a common front, the lack of a shared economic theory frequently weakens ND's arguments, especially in more academic debates and in the evaluation of policy alternatives. Bresser-Pereira et al. (2016) decided to face the challenge of beginning to systematically build such a theoretical foundation for ND policies. For the purposes of this note, we are interested in discussing one point of the theory, albeit a rather essential one, that is the concepts of current and industrial equilibrium exchange rates and the relationship between them. In what follows we first examine the way those rates are defined and are proposed to behave in order to develop some ideas about the policies that are expected to bring about the correct relationship between the two. Since to a larger extent the purpose of BresserPereira et al. (2016) is to systematize a theoretical basis for ND, it could be expedient to observe at this point that the question of exchange rates is discussed in this paper from a Keynesian point of view ${ }^{2}$, based on concepts first published by Keynes in 1923, in his A Tract on Monetary Reform.

\section{EXCHANGE RATES IN ND ${ }^{3}$}

In a nutshell, ND relies on the notion that (1) modern medium income developing economies tend to be especially vulnerable to durable episodes of currency overappreciation; (2) as a result, manufacturing industries, even those capable of

\footnotetext{
${ }^{1}$ Even at this general level, however, some disagreements seemed to have been important enough to lead a dissident group to stress a more independent position, which has been called social developmentalism.

${ }^{2}$ Bresser-Pereira et al. (2016) makes a distinction between Keynesian and Post-keynesian views, having in mind, naturally, that "Keynesian" models maintain only a tenuous relation to Keynes's own ideas, as expressed mainly (but far from exclusively) in The General Theory. The distinction is accurate and in most contexts, including that in which the book was written, necessary, since the authors are discussing in fact propositions advanced both by neoclassical synthesis Keynesians and by Post-keynesians who try to develop Keynes's own insights. In this paper, however, no mention will be made of neoclassical synthesis Keynesian concepts. For that reason, in the interest of simplicity, we will refer as Keynesian ideas proposed by Keynes himself and those who claim his legacy.

${ }^{3}$ In what follows I will use ND as a short hand for Bresser-Pereira et al. (2016) arguments, neglecting other new developmentalist views on the same subjects, unless noted otherwise.
} 
producing with "state-of-the-art" techniques, cannot maintain their competitiveness, losing both their export and domestic markets to foreign competitors.

To discuss these two propositions, ND proposes two definitions of equilibrium exchange rates: (1) the current equilibrium exchange rate is the rate that guarantees a balanced current account, without surpluses or deficits; and (2) the industrial equilibrium rate is that exchange rate that allows the survival in domestic and external markets of manufacturing firms operating with state-of-art techniques. In the authors' view, the current equilibrium exchange rate seems to define some kind of "natural" position of the system, that should emerge when no non-systematic forces are in operation. Current exchange rates, according to ND, are determined by current supply and demand for foreign currency. Therefore, they may be influenced by random, non-systematic forces in operation at any given moment. ND, however, assumes that such situations, being random in nature, cannot last. Current equilibrium exchange rates should be understood as a kind of gravity center around which actual rates should fluctuate. In contrast to current equilibrium exchange rates, industrial equilibrium exchange rates should not be expected to prevail without explicit policy support. It cannot prevail "naturally" since it does not reflect the market forces operating in the market for foreign currencies. It is left to the state to act to constrain some of those market forces to allow industrial equilibrium exchange rates to impose themselves.

According to ND, two major obstacles stand in the way of the industrial equilibrium exchange rate. First, and receiving the lion's share of Bresser-Pereira and his co-authors' attention, there is the Dutch disease, whereby some mineral and agricultural goods may be produced in some countries with such a competitive advantage that they generate large inflows of foreign currency leading to a sharp increase in the external value of the domestic currency. The authors see the Dutch disease as the most serious problem because they view it as a "structural" problem, created by the natural abundance of some natural resources in a given country. The Dutch disease is characterized as a market failure, whereby the foreign exchange market sets "wrong" relative prices that make it impossible for local industries, even those operating with state-of-art techniques, as they stress, to compete.

The second obstacle is given by excess inflows of financial capital, motivated either by domestic interest rate policies or by some random changes in expectations of foreign financial investors. This is clearly considered a minor problem, at least in comparison with the Dutch disease. The reasons seem to be (1) that interest rate policies can be changed, eliminating thereby a systematic cause for overappreciation; (2) autonomous changes in expectations are assumed to be random in nature so that their influence is expected to dissipate in longer stretches of time.

ND assumes, therefore, that trade is the only permanent source of the impulses that are durably expressed in the behavior of exchange rates, both actual 
and current equilibrium exchange rates. ${ }^{4}$ Policies designed to make industrial equilibrium exchange rates to prevail must, therefore, address those trade imperfections that prevent technologically advanced manufacturing firms to operate in developing economies like Brazil's. Capital movements seem to have their influence relegated to the creation of short-term volatility in actual exchange rates. They cannot influence in any durable war the current equilibrium exchange rate, let al.one the industrial equilibrium rate. ${ }^{5}$

\section{CAPITAL FLOWS AND EXCHANGE RATES}

From a Keynesian point of view, the formulation just discussed, despite its many novel aspects, is still a traditional view of foreign currency markets, which assumes that trade always prevails over finance, at least in the longer term. Finance is considered, but less as an autonomous activity than as an auxiliary to trade, the shadow of current account disequilibria. It is assumed that, ultimately, capital flows result from current account imbalances. The possibility is not contemplated that financial in and outflows may generate persistent pressures on exchange rates, in one direction or another, by themselves.

This perspective was probably appropriate for a long part of modern capitalism's history. Even the "first" globalization wave, led by Great Britain in the late nineteenth century, had financial flows as essentially derived from "real" causes, to finance trade or to support foreign direct investment related to trade activities. One can be less sure, however, that this hierarchy of determinants is still valid nowadays when financial flows are in fact mostly disconnected from trade activities. They are essentially autonomous in nature and are much larger in volume than trade pay-

\footnotetext{
${ }^{4}$ In private communication, Professor Bresser-Pereira points out that I may have taken too extreme a view of the determinants of the exchange rate according to ND. He clarified that trade factors take the exchange rate to its "current equilibrium", but observable values of the exchange rate are also a result of the excess demand for foreign currency resulting from international flows of financial resources. The difference that still separates our arguments may have to do with the emphasis given by Bresser-Pereira, Oreiro and Marconi to domestic-policy-induced changes in those financial flows while I am proposing that similar movements are likely to take place even in the absence of those policies identified by them. As observed in this paper, I do not think these are unsurmountable differences between the two approaches. Its importance may reside, as argued below, in the fact that domestic policies to contain overappreciation may be harder to design in the face of systematic but autonomous international financial flows.

${ }^{5}$ The "unpredictable behavior" of financial flows is mentioned or assumed in various points of the book. Financial liberalization is blamed for increasing volatility, that is, the amplitude of variations around a given norm which seems itself to be immune to those flows. See, for instance, Bresser-Pereira et al. (2016, pp. 53/54) Among the consequences of such approach to financial flows, we see that the definition of the "value" of the exchange rates refers to its "fundamental price", that is, that which "the firms that participate in the country's foreign trade need to export and ensure equilibrium in its current account." (id: 56, my emphasis). Later, the authors advance the concept of a true equilibrium exchange rate which does not consider any financial factor (id., p. 74).
} 
ments. More importantly, they are not erratic, or the result of temporary fluctuations, at least if we take "temporary" to mean reasonably short periods of time.

We should distinguish two different types of capital flows: (1) foreign direct investment (FDI); and (2) portfolio flows. Even though foreign direct investment flows nowadays evolved to become a much complex variable than it used to be not so long ago, it may be reasonable to assume that they still depend on expectations of returns to be obtained in recipient countries and factors like the availability of a skilled labor force, tax incentives and other variables that help to determine markets and expected costs and profits. Under modern conditions of productive international integration, where multinational firms choose national locations for productive facilities to perform definite tasks in the production process of a given product, decisions related to the specific destination of FDI flows are certainly not erratic or temporary.

But portfolio flows are not erratic either even when they are induced by arbitrage opportunities. In fact, the most original contribution made by Keynes in 1923 to the study of exchange rate behavior was exactly to show that such flows are not erratic.

In that work, Keynes criticized the emphasis on trade as the determinant of exchange rates. Keynes, still loyal to the classical theory in which he was trained, did not reject the purchasing power parity (PPP) theory of exchange rates that constituted an important element of its framework. Keynes understood the PPP, in its most influential form at the time, proposed by Gustav Cassel, as a theory of long run equilibrium exchange rates. ${ }^{6}$ In his view, however, like the quantity theory of money on which foundations it was built, PPP was not a useful guide to understand actual events and to design appropriate policies. Keynes built an alternative approach, which became known as interest rate parity theory, which had as a starting point precisely the opposite assumption to that of classical thought: portfolio in and outflows were not random or erratic. Their movements could be logically explained and in fact predicted as systematically as movements due to trade movements. More importantly, perhaps, it could also explain why some forms of disequilibrium in the capital account could persist for long periods of time, independently of what could be happening in the current account of the balance of payments.

The approach is well known by now, having been adopted by many analysts and been included in standard textbooks on international economics. In a nutshell,

\footnotetext{
${ }^{6}$ One has to remember that it was in this book that Keynes wrote one of his most famous phrases, "in the long run we are all dead". The phrase was used to suggest the practical (and policy) irrelevance of statements based on long run equilibrium positions, not, as many seemed to have interpreted, usually taking the statement out of its original context, as the uselessness of thinking (and planning) for the long term. It may be worth to reproduce the entire statement: "But this long run is a misleading guide to current affairs. In the long run, we are all dead. Economists set themselves too easy, too useless a task if in tempestuous seasons they can only tell us that when the storm is long past the ocean is flat again." (Keynes, 2013, p. 65)
} 
Keynes's formulation can be better understood through an example: let us consider two countries, the "US" and "GB", the first issuing dollars, the second pounds. In the US, the interest rate paid on one-year Treasury bills is, say, $3 \%$. The equivalent rate in $\mathrm{GB}$ is $2 \%$. The spot exchange rate $\$_{\mathrm{US}} / \hat{E}_{\mathrm{GB}}$ is 1 at the beginning of the period. Let us assume that the forward rate of exchange for liquidation one year later is $\$ 1.05$ to the pound, as informed by forward markets. In other words, the dollar is expected to devalue $5 \%$ in the period. An investor in, say, GB having $£ 1$ to invest, can do it in the US and end up with $\$ 1.03$ at the end of the year or in GB and end up with $£ 1.02$. However, at the end of the period, if the investor in GB intends to repatriate her investment, she will have to buy pounds at the higher price of $\$ 1.05$ per pound. The proceeds of the investment, measured in pounds, then will be $£ .98$, instead of $£ 1.02$ she would get had she invested her money in GB Treasury bills instead of US Treasury bills. Making these calculations in advance not only leads the investor in GB to hold her pounds to invest in GB but will also lead investors in the US to do the same, that is, to invest in GB Treasuries. In the latter case, US investors would get a lower interest income in GB but the devaluation of the $\$$ would increase their gains beyond what they could get had they held their investments in the US. In other words, investors in the US will try to buy pounds to invest in GB, and GB investors will hold their pounds to remain invested in GB. This will increase the value of the pound with respect to the dollar, that is, will raise the spot exchange rate closer to the forward exchange rate, reducing the return differential between investment in the two currencies.

This mechanism would determine the spot, or current, exchange rate from the expected rate of exchange for the relevant future date and the interest rates of the relevant countries for the relevant maturity. One would expect that in equilibrium net inflows would be zero, since expected proceeds would be the same in the two countries at that equilibrium spot exchange rate measured in any one of the two currencies. ${ }^{7}$ On the other hand, if there was reason for investors to expect one of the currencies to reach continuously increasing values in the future, the disequilibria would be continuously recreated, period after period. If, for instance, it can be expected that interest rates in country 1 will be maintained persistently above the rates observed in other countries, there will emerge a trend to overvalue country 1's currency and disequilibria will not be eliminated. In this case, a vicious circle is created in which high relative interest rates attract financial inflows that increase the value of the local currency and make it doubly attractive: one can get more interest revenues and to gain from capital gains in the appreciation of the currency. Instead of the equilibrating mechanism one would expect, we find that appreciation in the spot market feeds expectations of further appreciation in the future.

Can it last forever? Well, it does not have to last forever. If it lasts a long time,

\footnotetext{
${ }^{7}$ The mechanism is easily generalized to the cases where countries not only pay different interest rates but are also different in their risk characteristics.
} 
it may cause irreparable damage to manufacturing firms by reducing their competitiveness. Besides, there is no need to assume that foreign currency market investors believe it will last forever. Everybody knows that nothing lasts forever and financial investors are not less rational than others. The point is not to know that unsustainable configurations will not be sustained forever, but that no one knows when a change of direction will happen. Some investors will be more cautious and dispose of their positions in the overvalued currency earlier, exposing themselves to the criticism that they lost money because they were too cautious. Others will leave too late and will be called speculators and blamed for a crash. It is not different from what happens with the business cycle itself. The phenomenon has been known and exhaustively described for more than one hundred years but businesses still overinvest in the boom and crash in the recession. Uncertainty as to the precise moment to stop will always cause such a pattern of dispersion.

Keynes formulated the theory while still publicly adhering to classical economics. Nevertheless, it was never abandoned. As it is well known, The General Theory was written having a closed economy in mind, but the interest rate parity theory described in 1923 is generalized to determine current (spot) prices of all assets in chapter 17 of the GT. ${ }^{8}$

The assumption that determination of spot exchange rates was dependent on expectations about future exchange rates was also not different from the notion of speculative motive to demand money, where current interest rates depend on expected interest rates. The role of expectations in this theory is paramount, as in everything else in Keynes, but expectations are not erratic or irrational. Keynes explicitly rejected the notion that expectations were "irrational", even though in important senses they could be autonomous (in fact, the longer the time horizon considered, the more autonomous with respect to current conditions they were supposed to be). There was an "equilibrium position" from which one could understand disequilibria. As the relevant variables that determine exchange rates in the interest rate parity model become more and more important, the less dependent on trade conditions the exchange rate becomes. This does not subtract from the importance of the presence of factors such as the Dutch disease. The case of Brazil in recent years suggest that the combined action of both trade and autonomous financial flows may be overwhelming. But, again, from a Keynesian point of view, there is no reason to dismiss financial factors as at most temporary influences explaining appreciation of the currency. In fact, if one considers the evolution of current account balances in Brazil since 1990 (Figure 1), one would expect to see pressures to devaluation that did not materialize. Financial net inflows, both FDI and portfolio investment, did not simply finance current account deficits. They were much bigger than that, allowing the country to build international reserves that reached US\$ 370 billion in the early months of 2017 .

\footnotetext{
${ }^{8}$ The path followed by interest rate parity theory of 1923 to become the own-rates of interest model of chapter 17 of the GT is brilliantly explained in Kregel (1982).
} 
Figure 1: Current Account Balances as a Percentage of GDP

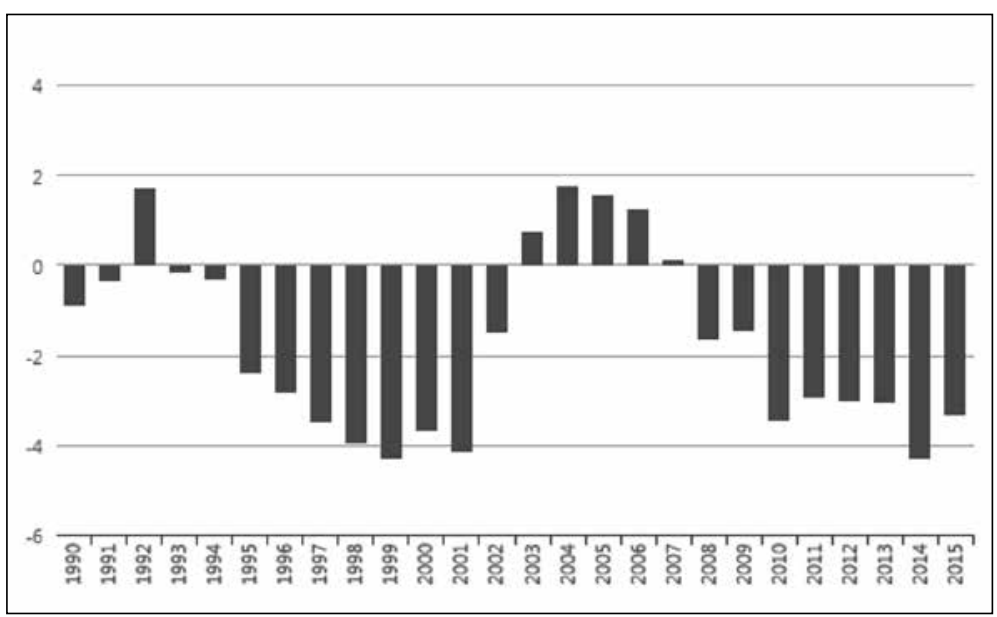

Source: CEPAL (http://estadisticas.cepal.org/cepalstat/Perfil_Nacional_Economico. html?pais=BRA\&idioma=english) .

One important implication of this realization is that policies designed to reach what ND defines as industrial equilibrium exchange rates must not only consider how to neutralize the Dutch disease but also how to prevent capital inflows from continuously appreciating the local currency.

\section{CURRENT AND INDUSTRIAL EQUILIBRIUM EXCHANGE RATES UNDER CAPITAL ACCOUNT LIBERALIZATION}

Bresser-Pereira et al. (2016) exhaustively explains why one should expect currency appreciation to become a trend in countries endowed with rich reserves of natural resources. In countries like Brazil, where powerful forces pushing up inflation survived the successful 1994 inflation stabilization plan were combined with the adoption of inflation targeting as their monetary policy regime in 1999, to strengthen the appreciation the trend trend (Cardim de Carvalho, 2016). Brazilian recent experience shows that if inflation remains high and is combatted purely with higher interest rates, one can expect currency appreciation even if foreign trade shows deficits because of the operation of mechanisms such as those described in the preceding section. If strong flows of incoming foreign direct investment are added to the picture, appreciation pressures tend to become even more acute. Under liberalized capital accounts, financial flows frequently come to dominate trade flows and actual exchange rates can end up responding more effectively to financial flows than to trade. ${ }^{9}$

\footnotetext{
${ }^{9}$ One would expect financial flows to be more voluminous and volatile than trade flows. One basic financial operation tends to involve, through leverage and overlayering, values that are much bigger
} 
If financial flows do dominate trade flows, the task of policy makers trying to reach industrial equilibrium becomes much more complicated. Not that they are simple in the absence of the problems caused by open capital accounts. There are clear difficulties surrounding attempts to tax primary exports to fight Dutch disease, as prescribed by ND, which may seem, at the eyes of the public opinion, an attempt to penalize successful enterprises to subsidize failing manufacturing firms. ${ }^{10}$ There are politically influential constituencies who benefit from currency appreciation, from businesses that rely on imports to the middle classes for whom an appreciated currency opened access to imported goods and to services like international tourism. One has also to consider that currency appreciation can be a powerful instrument to control inflation, a sensitive issue in societies that suffered from inflationary traumas. Beyond all these well-known obstacles to fighting appreciation through taxing primary goods exports, it is important to remember that, with liberalized capital accounts, pressures to continuing currency appreciation can still be originated by excess capital inflows that would not be affected by the measures prescribed by ND to fight the Dutch disease.

The implementation of capital controls would be the logical solution to the appreciation conundrum. One has to keep in mind, however, that by now a large number of developing countries have already dismantled the controls they used to have and it is much more difficult to reinstate controls than to maintain them. ${ }^{11}$ BresserPereira et al. (2016) insist that controls should be imposed on inflows, not on outflows. It certainly is the case when the problem is currency overappreciation, but when dealing with capital controls a broader view could be more efficient. When dealing with inflows from non-residents, controls should be imposed at entry. The Chilean experience showed that controls can be efficiently imposed to fight excess capital inflows. But controls on outflows should be kept as an option to stop capital flight from residents when the perception spreads that a balance of payments crisis is imminent. In other words, preventing non-residents to return may be construed as a violation of a contract on the part of the recipient country. If the financial resources from abroad are judged to be undesirable, what one should do is to prevent them from coming to the country. Residents, on the other hand, have no "right of return".

than the original (for instance, one financing operation may involve securitization and other forms of refinancing, creation of derivatives, currency swaps, and so on). The expectation of balance of payments problems affect marginal flows in trade (new exports or imports) but may affect stocks of financial assets (capital floods or capital flights). Trade operations require some time to be changed, contracts to be modified, while financial operations may be changed in the duration of a phone call or an electronic message. Finally, financial transaction costs are much lower than trade transaction costs, so that minute changes in prices of assets may have a much larger impact on operations than equivalent changes in the prices of goods.

${ }^{10}$ One can remember how polemical was the decision of the Kirchner government in Argentina to tax beef exports.

${ }^{11}$ The difficulties faced by the Brazilian government in the mid-2010s to impose controls on capital inflows illustrate the point. 
Balance of payments crises also cause serious negative externalities on other domestic agents and should be prevented by controls on outflows if necessary. But we certainly agree with ND that controls on outflows on the part of non-residents should be a very last resort instrument, as it was the case of Malaysia in 1998.

\section{CONCLUSION}

From a Keynesian point view, ND would gain theoretical density if it gave more attention to some of the autonomous financial variables that act in the process of determination of exchange rates. Extending the model to fully consider financial in and outflows would strengthen what now seems to result more from an intuition than an implication of the theory: the need for capital controls, especially for prudential considerations.

Many orthodox economists argue that ND's emphasis on manufacture is obsolete. Nevertheless, governments of advanced economies are all seeking ways to strengthen their own national manufacturing sectors. Orthodox tales about the equal chances of success of economies that rely on primary exports have found more appreciative readers in developing economies. Dispelling these illusions is perhaps the main goal of new developmentalism in all of its forms. The concept of industrial equilibrium exchange rates is a distinctive contribution of Bresser-Pereira et al. (2016) to the badly needed debate on how to rediscover a development path that has showed itself to be so elusive in recent decades in Latin America. Of course, exchange rate policies are central to any such development strategy, but are far from enough to guarantee that any given economy will remain in the virtuous path long enough to make the transition to developed status. Having said that, however, it is also clear that relative prices matter and in this sense the ND is right on the mark.

\section{REFERENCES}

Bresser-Pereira, L.C., Oreiro, J.L. and Marconi, N. (2016) Macroeconomia Desenvolvimentista. Teoria e Politica Economica do novo desenvolvimentismo, Rio de Janeiro: Elsevier Editora.

Cardim de Carvalho, F. J. (2016) "Looking into the Abyss? Brazil in the mid-2010s", Journal of Post-keynesian Economics, 39 (1), 93-114.

Keynes, J.M. (2013) A Tract on Monetary Reform, vol IV of D. Moggridge (ed), The Collected Writings of John Maynard Keynes, Cambridge: Cambridge University Press for The Royal Economic Society (published originally in 1923).

Kregel, J. (1982), “Monnaie, anticipations et prix relatifs”, Economie Appliquee, 3. 